\title{
Kriteria Penentu Lokasi Agroindustri Berbasis Komoditas Jagung di Kabupaten Jombang
}

\author{
Febri Fitrianingrum dan Belinda Ulfa Aulia \\ Perencanaan Wilayah dan Kota, Fakultas Arsitektur Desain dan Perencanaan, \\ Institut Teknologi Sepuluh Nopember (ITS) \\ e-mail: b3ltown@gmail.com
}

\begin{abstract}
Abstrak-Kabupaten Jombang memiliki potensi pada bidang pertanian berupa penggunaan lahan di dominasi oleh lahan pertanian sebesar $103.344 \mathrm{Ha}$ atau sebesar $86,54 \%$ dari total luas penggunaan lahan. Berdasarkan data dari tahun 20122017 pertumbuhan produksi jagung di Kabupaten Jombang cenderung mengalami peningkatan. Berdasarkan realisasi investasi penanaman modal asing dan dalam negeri sektor sekunder di Provinsi Jawa Timur tahun 2017, Kabupaten Jombang menempati urutan ke-8 dengan jumlah investasi industri 102.850.000 US\$. Namun apabila dibandingankan dengan kondisi eksisting, di Kabupaten Jombang hanya memiliki 1 industri besar dan 1 industri sedang pengolahan berbasis jagung. Tersedianya 1 industri besar pengolahan jagung dapat diartikan pengolahan komoditas jagung di Kabupaten Jombang belum sepenuhnya berkembang, sehingga perlu dilakukan kajian kriteria penentu lokasi agroindustri komoditas jagung. Pada penelitian ini variabel yang berpengaruh terhadap penentuan lokasi agroindustri berbasis komoditas jagung didapatkan dari diskusi literatur penelitian sebelumnya, yang selanjutnya dianalisis menggunakan analisis deskriptif kualitatif pada penyusunan kriteria lokasi agroindustri. Hasil dari penelitian ini didapatkan delapan kriteria yaitu kondisi fisik dasar, aksesibilitas, tenaga kerja, bahan baku, sarana dan prasarana pendukung, aglomerasi, kelembagaan, serta kesesuaian lahan yang dapat diidentifikasi menggunakan software ArcGIS 10.4 menghasilkan tipologi kesesuaian lokasi agroindustri komoditas jagung di Kabupaten Jombang.
\end{abstract}

Kata Kunci-Komoditas Jagung, Agroindustri, Lokasi Industri Pengolahan.

\section{PENDAHULUAN}

A GROINDUSTRI merupakan bagian dari agribisnis yang memproses dan mentransformasikan bahan hasil pertanian menjadi barang setengah jadi yang dapat dikonsumsi langsung dan barang atau bahan hasil produksi yang digunakan dalam proses produksi. Pengembangan agroindustri digunakan untuk mewujudkan sektor pertanian yang tangguh, maju, serta efisien sehingga mampu menjadi leading sector dalam pembangunan nasional [1]. Penduduk Kabupaten Jombang bekerja paling banyak dalam sektor pertanian sebesar 27,94\% dari total penduduk yang bekerja. Penggunaan lahan di Kabupaten Jombang di dominasi oleh penggunaan lahan untuk pertanian yaitu sebesar $103.344 \mathrm{Ha}$ atau sebesar $86,54 \%$ dari total luas penggunaan lahan [2]. Berdasarkan PDRB berdasarkan harga konstan tahun 2010, sektor pertanian telah menyumbang sebesar 20,2\% dari seluruh sektor lapangan usaha yang ada di Kabupaten Jombang serta dari seluruh sektor pertanian, sub sektor tanaman pangan menyumbang sebesar 40,62\%. Ditinjau dari pertumbuhan ekonomi wilayah Kabupaten Jombang yang menitikberatkan pada sektor pertanian, ternyata memiliki laju pertumbuhan ekonomi Kabupaten Jombang masih di bawah rata-rata pertumbuhan ekonomi Kabupaten/Kota se-Jawa Timur. Berdasarkan data PDRB Kabupaten/Kota se-Jawa Timur tahun 2012-2016, laju pertumbuhan ekonomi ekonomi di Jawa Timur sebesar 5,55\%, sedangkan laju pertumbuhan ekonomi Kabupaten Jombang hanya sebesar 5,40\%. Dengan demikian pertumbuhan ekonomi di Kabupaten Jombang dapat dikatakan rendah karena masih dibawah rata-rata laju pertumbuhan ekonomi seluruh kabupaten di Jawa Timur [3].

Tentunya, hal tersebut berkesinambungan dengan visi penataan ruang wilayah Kabupaten Jombang sebagai wilayah pengembangan sentra agribisnis dan wilayah pengembangan industri yang berbasis pada potensi lokal yang berdaya saing. Dilihat dari sudut pandang sektor industri berdasarkan realisasi investasi penanaman modal asing dan dalam negeri sektor sekunder di Provinsi Jawa Timur tahun 2017, Kabupaten Jombang menempati urutan ke-8 setelah Kota Surabaya dan Kabupaten Tuban dengan jumlah investasi industri 102.850.000 US\$.

Untuk mendukung kegiatan pada sistem agroindustri, Kabupaten Jombang memiliki keunggulan komparatif berupa sumber daya alam yang melimpah dan memiliki komoditas unggulan yang mampu mendorong pertumbuhan ekonomi. Komoditas jagung di Kabupaten Jombang pada tahun 20102014 secara umum mengalami peningkatan yang cukup baik di tiap tahunnya. Namun pada tahun 2013 terjadi penurunan jumlah produksi sebesar 45,314 dari tahun 2012. Kondisi ini disebabkan karena adanya perubahan iklim yang tidak menentu di tahun tersebut, namun kondisi tidak berlangsung lama dan pada tahun berikutnya produksi jagung mengalami peningkatan kembali sebesar 36,095 ton. Jika dilihat dari tren lima tahun terahir pertumbuhan produksi jagung di Kabupaten Jombang masih mengalami peningkatan dengan tren pertumbuhan naik, sehingga komodias jagung masih memiliki peluang yang besar untuk dikembangkan [4].

Namun kondisi pengeolahan jagung di Kabupaten Jombang hanya terdapat 1 industri besar dan 1 industri sedang, yaitu industri pakan ternak yang berada di Kecamatan Mojoagung serta industri beras jagung di Kecamatan Ngoro. Bahan hasil produksi jagung mayoritas akan langsung dijual ke luar kota. Dilihat dari adanya industri berdasarkan ukurannya, berdasarkan data BPS Kabupaten Jombang tahun 2016 di Kabupaten Jombang tersedia 10 industri besar, 30 industri menengah, serta 552 industri kecil. Tersedianya 1 industri besar dan 1 industri sedang pengolahan jagung dapat diartikan pengolahan komoditas jagung di Kabupaten Jombang belum sepenuhnya berkembang [5].

Adanya arahan pengembangan untuk agroindustri merupakan optimalisasi untuk sektor industri yang ada di Kabupaten Jombang. Namun pada kondisi eksisting hanya terdapat 2 industri pengolahan yang mampu menampung produksi jagung. Sehingga penelitian ini bertujuan untuk 
menentukan kriteria lokasi agroindustri yang berbasis komoditas jagung di Kabupaten Jombang.

\section{METODE PENELITIAN}

Tahap pertama dari penelitian ini adalah menentukan variabel yang berpengaruh terhadap penentuan lokasi agroindustri komoditas jagung. Variabel yang dikaji merupakan variabel yang berasal daridiskusi literatur penelitian sebelumnya. Variabel yang digunakan pada penelitian ini bisa dapat dilihat pada tabel 1. Selanjutnya untuk menyusun kriteria lokasi agroindustri komoditas jagung di Kabupaten Jombang digunakan analisis deskriptif kualitatif. Analisis deskriptif kualitatif dilakukan dengan mengkaji peraturan dan standar terkait pembangunan industri, literatur, serta studi kasus yang sesuai dengan variabel dan sub variabel penelitian yang sesuai dengan pembangunan industri [6]-[8].

Analisis ini menggunakan peraturan dan standar antara lain Peraturan Menteri Perindustrian nomor 40 tahun 2016 tentang pedoman teknis Kawasan industri, Peraturan Menteri Pekerjaan Umum nomor 41 tahun 2007 tentang pedoman kriteria teknis Kawasan budi daya, Peraturan Menteri dalam Negeri nomor 33 tahun 2006 tentang pedoman umum mitigasi bencana, Keputusan Menteri Permukiman dan Prasarana Wilayah nomor 534/KPTS/M/2001 tentang pedoman penentuan standar pelayanan minimal bidang penataan ruang. Analisis deskriptif tersebut menghasilkan kriteria yang digolongkan menjadi tiga kelas kesesuaian, yaitu tidak sesuai, cukup sesuai, dan tidak sesuai.

Tabel 1.

Variabel Penelitian

\begin{tabular}{|c|c|}
\hline Indikator & Variabel \\
\hline Kondisi Fisik Dasar & $\begin{array}{l}\text { Kemiringan Lahan } \\
\text { Jenis Tanah } \\
\text { Kerawanan Bencana }\end{array}$ \\
\hline Aksesibilitas & Ketersediaan Jaringan Jalan \\
\hline Tenaga Kerja & Jumlah Tenaga Kerja Industri Pengolahan \\
\hline Bahan Baku & Ketersediaan Bahan Baku \\
\hline $\begin{array}{l}\text { Sarana dan Prasarana } \\
\text { Pendukung }\end{array}$ & $\begin{array}{l}\text { Ketersediaan Jaringan Listrik } \\
\text { Ketersediaan Jaringan Air } \\
\text { Ketersediaan Jaringan Telekomunikasi }\end{array}$ \\
\hline Aglomerasi & Jumlah Industri Sejenis \\
\hline Kelembagaan & $\begin{array}{l}\text { Ketersediaan Kelompok Usaha Tani } \\
\text { Ketersediaan KUD }\end{array}$ \\
\hline Kesesuaian Lahan & $\begin{array}{l}\text { Kesesuaian Lahan Zona Industri } \\
\text { Luasan Lahan Industri }\end{array}$ \\
\hline
\end{tabular}

\section{HASIL DAN PEMBAHASAN}

Ruang lingkup wilayah penelitian ini meliputi seluruh kecamatan yang ada di Kabupaten Jombang. Luas wilayah Kabupaten Jombang yaitu 1.159,50 km². Kabupaten Jombang berbatasan dengan Kabupaten Bojonegoro dan Kabupaten Lamongan di sebelah utara, berbatasan dengan Kabupaten Kediri dan Malang di sebelah Selatan, berbatasan dengan Kabupaten Mojokerto di sebelah timur, serta berbatasan dengan Kabupaten Nganjuk di sebelah barat.

Pada penelitian ini terdapat delapan kriteria dan empat belas sub kriteria berdasarkan indikator dan variabel yang disusun menggunakan analisis deskriptif. Setiap sub kriteria dipetakan menjadi tiga kelas kesesuaian yaitu warna hijau yang berarti area yang sesuai, warna kuning sebagai area cukup sesuai, serta warna merah sebagai area tidaksesuai yang diolah menggunakan software ArcGIS 10.4.

\section{A. Kriteria Kondsi Fisik Dasar}

Kriteria yang diolah untuk yang pertama yaitu kriteria kondisi fisik dasar. Dimana pada kriteria ini memiliki tiga sub kriteria yaitu kemiringan lahan, jenis tanah, serta kerawanan bencana. Menurut Peraturan Menteri Perindustrian nomor 40 tahun 2016 tentang pedoman teknis pembangunan kawasan industri, kemiringan lahan yang sesuai untuk kegiatan industri adalah maksimal sebesar 15\%. Pada kemiringan lebih dari 15\% masih dapat dikembangkan untuk kegiatan industri dengan perbaikan kontur sehingaa akan mempengaruhi biaya dan teknologi konstruksi yang digunakan.

Pemilihan lokasi peruntukan kegiatan industri hendaknya dipilih pada areal lahan yang memiliki topografi yang relatif datar. Kondisi topografi yang relatif datar akan mengurangi pekerjaan pematangan lahan (cut and fill) sehingga dapat mengefisiensikan pemanfaatan lahan secara maksimal, memudahkan pekerjaan konstruksi, dan menghemat biaya pembangunan. Oleh karena itu untuk kriteria kemiringan lahan, area yang sesuai untuk kegiatan industri adalah dengan kemiringan $0-15 \%$, area dengan kemiringan $16-40 \%$ sebagai area cukup sesuai, dan area dengan kemiringan lahan lebih dari $40 \%$ adalah area yang tidak cocok untuk pembangunan kegiatan industri. Sub kriteria kemiringan lahan pada wilayah penelitian dapat dilihat pada gambar 1 .

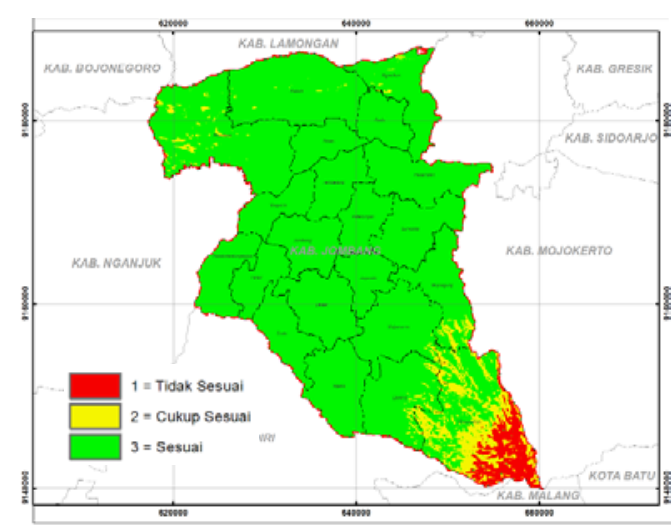

Gambar 1. Peta Sub Kriteria Kemiringan lahan

Untuk sub kriteria jenis tanah, tingkat kesuburan sangat tinggi dan baik bagi kegiatan pertanian, maka jenis tanah ini harus dipertahankan untuk kegiatan pertanian dan tidak direkomendasikan untuk kegiatan industri. Hal ini dilakukan untuk mencegah adanya konversi lahan pertanian Kabupaten Jombang yang mengakibatkan turunnya produktivitas pertanian guna menjaga ketahanan pangan. Menurut Peraturan Menteri Perindustrian nomor 40 tahun 2016, lokasi kegiatan industri tidak diijinkan pada lahan pertanian terutama areal pertanian lahan basah.

Pada Kabupaten Jombang sendiri terdapat beberapa jenis tanah yang cocok untuk pertanian, sehingga jenis tanah tersebut kurang cocok untuk kegiatan industri. Terdapat lima jenis tanah yang ada di Kabupaten Jombang yaitu tanah mediteran, andosol, grumosol, alluvial, dan litosol. Jenis tanah yang paling cocok untuk lokasi agroindustri adalah jenis tanah latosol dan mediteran dikarenakan memiliki tingkat keasaman yang tinggi sehingga menjadi kendala untuk pengembangan komoditas pertanian. Untuk tanah grumosol berasal dari batuan vulkanik/batu pegunungan yang memiliki kandungan bahan organik yang cukup rendah, sehingga cukup sesuai untuk lokasi agroindustri. Sementara untuk tanah alluvial dan andosol tidak sesuai untuk dijadikan lokasi industri dikarenakan memiliki tingkat kesuburan yang 
tinggi. Untuk peta sub kriteria jenis tanah dapat dilihat pada gambar 2 .

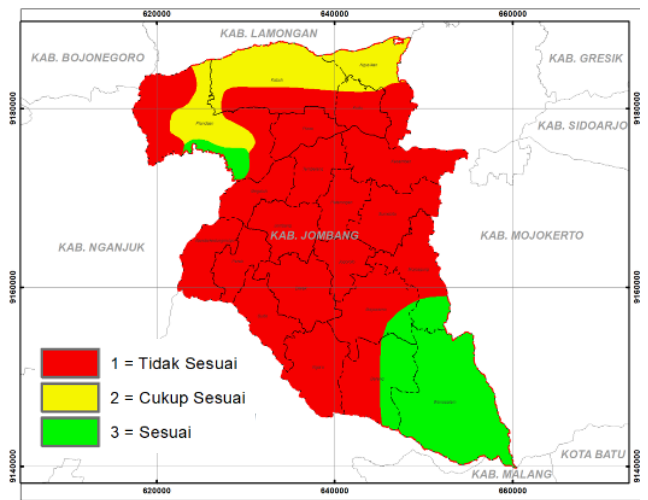

Gambar 2. Peta Sub Kriteria Jenis Tanah

Untuk sub kriteria kerawanan bencana Kabupaten Jombang memiliki potensi gempa tektonik yang rendah, dan gerakan tanah/longsor. Menurut Peraturan Menteri Dalam Negeri nomor 33 tahun 2006 tentang Pedoman Umum Mitigasi Bencana, daerah rawan bencana termasuk bencana tanah longsor masih bisa dijadikan lokasi industri sebagai upaya pencegahan perlu diberikan rekomendasi teknis tentang bagaimana menghadapi resiko bencana dan bencana susulan. selain itu perlu dilakukan identifikasi dan penilaian terhadap kerentanan area industri dan bangunan. Oleh karena itu daerah bebas bencana dianggap sesuai untuk lokasi agroindustri, daerah agak rawan sebagai area cukup sesuai, sedangkan daerah rawan bencana longsor dianggap tidak sesuai sebagai lokasi agroindustri. Sub kriteria kerawanan bencana dapat dilihat pada gambar 3 .

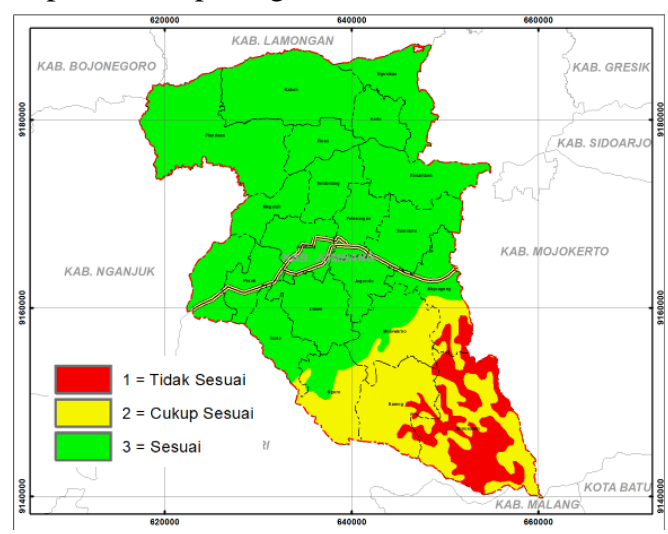

Gambar 3. Peta Sub Kriteria Kerawanan Bencana

\section{B. Kriteria Aksesibilitas}

Kriteria aksesibilitas terdiri dari sub kriteria ketersediaan jaringan jalan Jaringan jalan bagi kegiatan industri memiliki fungsi penting untuk kemudahan mobilitas pergererakan dan aksesibilitas logistik barang dan pergerakan manusia. Jaringan jalan untuk kegiatan industri memperhitungkan kapasitas jalan sebabagai upaya antisipasi kemacetan. Menurut Peraturan Menteri Perindustrian nomor 40 tahun 2016 tentang pedoman teknis pembangunan kawasan industri, lokasi industri sebaiknya terlayani oleh jaringan jalan arteri atau kolektor primer atau jaringan jalan dengan minimum $8 \mathrm{~m}$ untuk pergerakan lalu lintas kegiatan industri guna menghubungkan ke pelabuhan. Jaringan jalan yang dibutuhkan dalam menunjang kegiatan industri adalah jaringan jalan yang memiliki klasifikasi jalan arteri primer dengan jangkauan koridor $5 \mathrm{~km}$ diartikan sesuai sebagai lokasi industri. Area yang berada dalam jangkauan pelayanan arteri sejauh 6-10 km sebagai area yang cukup sesuai.
Sedangkan area yang berada diluar radius pelayanan jalan arteri diartikan tidak memenuhi kriteri lokasi agroindustri sehingga diidentifikasi sebagai area tidak sesuai. Berikut merupakan gambar 4 yaitu peta sub kriteria ketersediaan jaringan jalan.

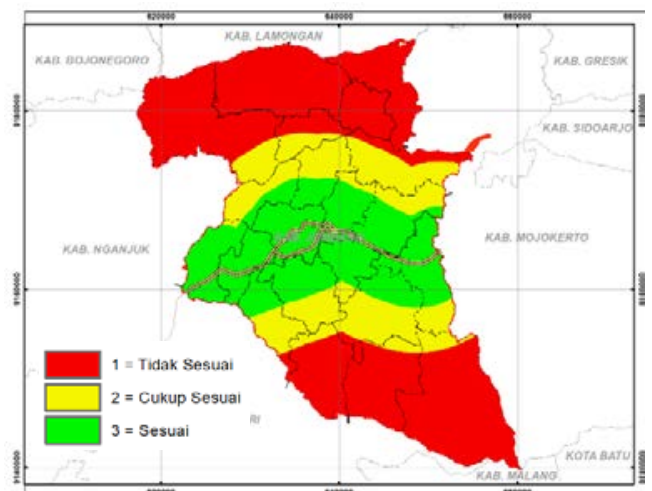

Gambar 4. Peta Sub Kriteria Ketersediaan Jaringan Jalan

\section{Kriteria Tenaga Kerja}

Kriteria tenaga kerja didefinisikan sebagai Besarnya jumlah tenaga kerja yang dibutuhkan oleh industri akan mempengaruhi pemilihan lokasi agroindustri. Dimana menurut BPS industri besar memiliki tenaga kerja minimal 100 orang atau lebih. Jumlah tersebut akan dibandingan denga jumlah usia produktif tiap kecamatan. Semakin banyak jumlah penduduk usia produktif dalam suatu kecamatan, maka kecamatan tersebut memiliki potensi tenaga kerja yang besar yang dapat mendukung kegiatan industri. Untuk menentukan kriteria ketersediaan tenaga kerja, maka digunakan rumus interval sebagai berikut.

$$
\begin{aligned}
\text { Interval } & =\frac{\text { Nilai Tertinggi }- \text { Nilai Terendah }}{\text { Jumlah Kelas }} \\
\text { Interval } & =\frac{101.381-14.868}{3} \\
& =28.838
\end{aligned}
$$

Berdasarkan perhitungan tersebut, kecamatan dengan jumlah penduduk usia produktif sebanyak 14.868-43.706 dianggap kurang sesuai sebagai lokasi agroindustri. Untuk kecamatan dengan jumlah penduduk usia produktif sebanyak 43.707-72.545 jiwa dianggap cukup sesuai. Sementara kecamatan dengan jumlah penduduk usia produktif 72.546101.381 jiwa dianggap sesuai sebagai lokasi agroindustri memiliki ketersediaan tenaga kerja paling banyak. Kemudian akan teridentifikasi kecamatan yang potensial untuk dijadikan lokasi agroindustri komoditas jagung. Peta ketersediaan tenaga kerja dapat dilihat pada gambar 5 .

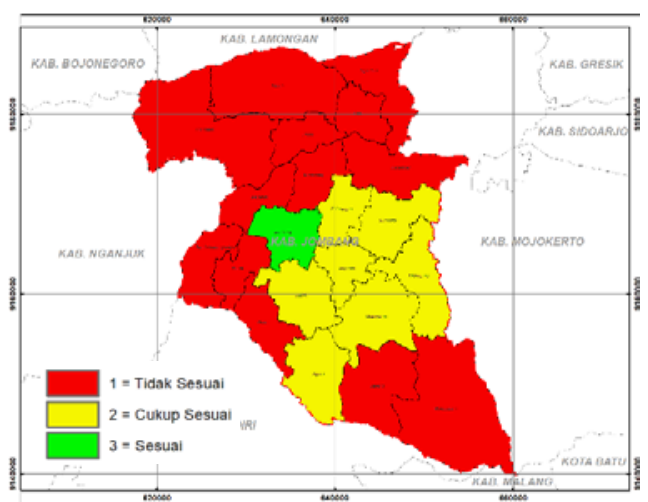

Gambar 5. Peta Ketersediaan Tenaga Kerja 


\section{Kriteria Bahan Baku}

Ketersediaan bahan baku merupakan faktor yang penting dalam pengembangan agroindustri. karena ketersediaan bahan baku berpengaruh terhadap jalannya produksi [9]. Dengan adanya lokasi industri pengolahan berbasis pertanian, diharapkan daerah sekitarnya mampu memasok bahan baku kegiatan industri yang terdapat pada wilayah tersebut [10]. Untuk menentukan kriteria ketersediaan bahan baku maka digunakan rumus interval berikut.

$$
\begin{aligned}
\text { Interval } & =\frac{\text { Nilai Tertinggi }- \text { Nilai Terendah }}{\text { Jumlah Kelas }} \\
\text { Interval } & =\frac{28.323-1.982}{3} \\
& =8.780
\end{aligned}
$$

Dari hasil analisis tersebut dapat disimpulkan bahwa kecamatan yang memiliki produksi komoditas sejumlah 19.544-28.324 ton jagung dinilai sesuai untuk lokasi agroindustri. Kecamatan dengan produksi jagung 10.76319.543 ton dinilai cukup sesuai Sementara kecamatan yang produksi jagung dengan jumlah 1.982-10.762 ton dinilai kurang sesuai untuk lokasi agroindustri. Peta ketersediaan bahan baku dapat dilihat pada gambar 6 .

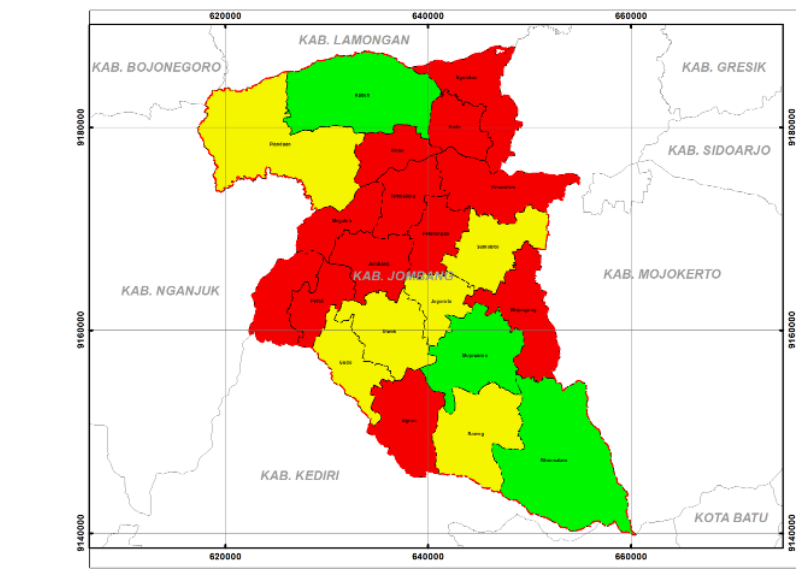

Gambar 6. Peta Ketersediaan Bahan Baku

\section{E. Kriteria Sarana dan Prasarana Pendukung}

Pada kriteria sarana dan prasarana pendukung, terdapat tiga sub kriteria yaitu sub kriteria ketersediaan jaringan listrik, ketersediaan air bersih, serta ketersediaan jaringan telekomunikasi.

Untuk sub kriteria ketersediaan jaringan listrik menurut Peraturan Menteri Perindustrian nomor 40 tahun 2016 tentang pedoman teknis pembangunan kawasan industri, instalasi penyediaan dan jaringan distribusi tenaga listrik dapat berasal dari PT. PLN atau sumber tenaga listrik yang diusahakan sendiri oleh swasta. Dalam penyediaan fasilitas kelistrikan perlu dialokasikan lahan untuk penempatan transformator listrik untuk menjaga kestabilan tegangan. Kapasitas yang diperlukan sebesar 0,15-0,2 MVA/ha. Oleh karena itu, kecamatan yang terlayani oleh jaringan listrik sejauh $<10 \mathrm{~km}$ dinilai sesuai sebagai lokasi agroindustri. Kecamatan yang dilayani oleh listrik sejauh 10-15 km dinilai cukup sesuai. Sementara kecamatan yang belum terlayani oleh jaringan listrik dinilai tidak sesuai sebagai lokasi agroindustri. peta ketersediaan jaringan listrik dapat dilihat pada gambar 7.

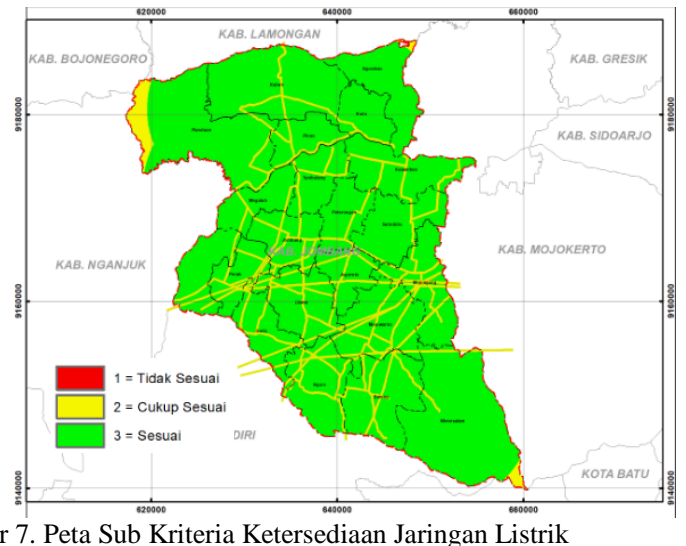

Gambar 7. Peta Sub Kriteria Ketersediaan Jaringan Listrik

Sub kriteria ketersediaan air bersih Berdasarkan Peraturan Menteri Perindustrian nomor 40 tahun 2016 tentang pedoman teknis pembangunan kawasan industri, kegiatan industri menggunakan sumber air baku yang memiliki debit air yang mencukupi untuk melayani kebutuhan kegiatan industri. Sumber air yang digunakan bisa berasal dari air permukaan (sungai, danau, waduk/embung, atau laut) atau sumber air tanah sesuai ketentuan yang berlaku ataupun PDAM. Jarak terhadap sungai atau sumber air bersih maksimum $5 \mathrm{~km}$. Sehingga, kecamatan yang telah terlayani oleh jaringan air bersih dinilai sesuai sebagai lokasi agroindustri. Sementara kecamatan yang tidak terlyani jaringan air bersih dinilai tidak sesuai sebagai lokasi agroindustri. Peta ketersediaan air bersih dapat dilihat pada gambar 8 .

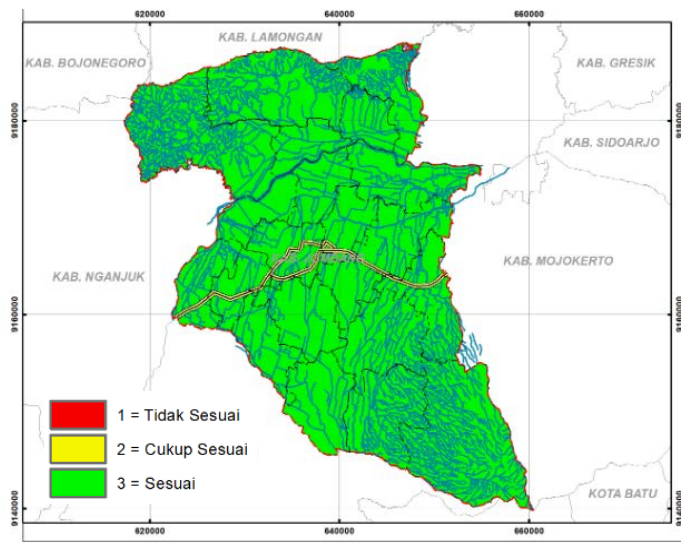

Gambar 8. Peta Sub Kriteria Ketersediaan Air Bersih

Sub kriteria jaringan telekomunikasi Menurut Peraturan Menteri Perindustrian nomor 40 tahun 2016 tentang pedoman teknis pembangunan kawasan industri, kegiatan industri membutuhkan dukungan tersedianya sistem dan jaringan telekomunikasi untuk kebutuhan telepon dan komunikasi data. Area yang terlayani oleh jaringan telekomunikasi harus memperhatikam lokasi BTS, sehingga area yang terpilih sebagai lokasi agroindustri masih berada pada jangkauan BTS. Jangkauan dari setiap menara BTS berbeda-beda, bergantung pada tinggi menara, jenis menara, kepadatan penduduk, hingga kontur tanah. Untuk itu diperlukan asumsi berdasarkan jangkauan rata-rata BTS yang didapatkan dari studi kasus untuk menentukan jangkauan BTS. Diasumsikan radius pelayanan satu menara BTS kurang lebih $7 \mathrm{~km}$ [10]. Dengan topografi wilayah yang relatif datar dan kepadatan penduduk yang beragam, maka jangkauan BTS diasumsikan mencapai $7 \mathrm{~km}$. Oleh karena itu area yang berada pada radius kurang dari $7 \mathrm{~km}$ dari titik menara BTS dianggap sesuai sebagai lokasi agroindustri, sementara area yang berada di luar radius $7 \mathrm{~km}$ diberi skor dinilai tidak sesuai sebagai lokasi 
agroindustri. peta ketersediaan jaringan telekomunikasi dapat dilihat pada gambar 9 .

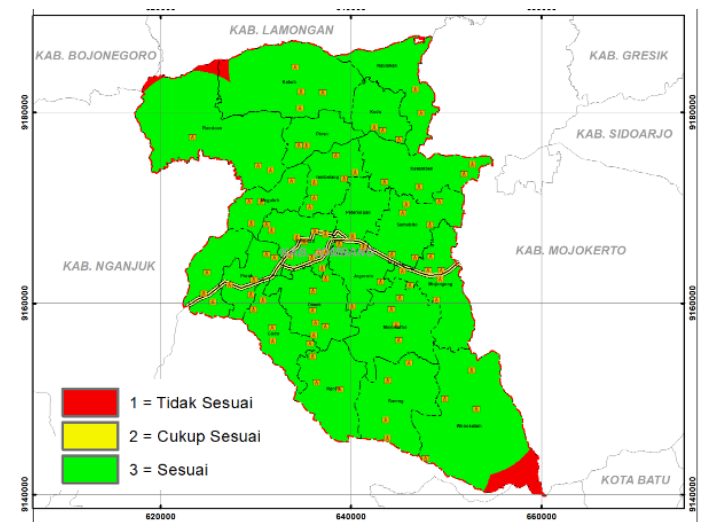

Gambar 9. Peta Ketersediaan Jaringan Telekomunikasi

\section{F. Kriteria Aglomerasi}

Pada kriteria aglomerasi bertujuan untuk meningkatkan daya saing industri, diperlukan pengelompokan industri yang saling berhubungan secara intensif. Pentingnya aglomerasi digunakan untuk mendapatkan penghematan baik tenaga kerja, bahan baku, maupu transportasi [11]. Pada kondisi eksisting, pada kawasan agropolitan Kabupaten Jombang masih belum berkembang. Industri yang sedang berkembang saat ini mayoritas berbahan baku kedelai dan kopi. Tidak semua kecamatan memiliki industri skala sedang-besar berbasis pertanian. Kecamatan terbanyak yang memiliki industri berbasis pertanian terdapat pada Kecamatan Jombang dengan jumlah 6 unit industri. Dapat diasumsikan bahwa semakin banyak industri pertanian pada suatu kecamatan, maka kecamatan tersebut dianggap lebih sesuai sebagai lokasi agroindustri. untuk mengetahui tingkat kesesuaian lokasi agroindustri, maka dilakukan perhitungan dengan rumus interval.

$$
\begin{aligned}
\text { Interval } & =\frac{\text { Nilai Tertinggi }- \text { Nilai Terendah }}{\text { Jumlah Kelas }} \\
\text { Interval } & =\frac{6-0}{2} \\
& =3
\end{aligned}
$$

Berdasarkan hasil perhitungan tersebut, kecamatan yang tidak memiliki industri pertanian dinilai kurang cocok untuk agroindustri. Kecamatan dengan industri pertanian berjumlah 1-3 unit dianggap cukup sesuai sebagai lokasi industri, sementara kecamatan dengan jumlah industri sebanyak 4-6 unit dianggap paling sesuai sebagai lokasi agroindustri. peta jumlah industri sejenis dapat diliha pada gambar 10 .

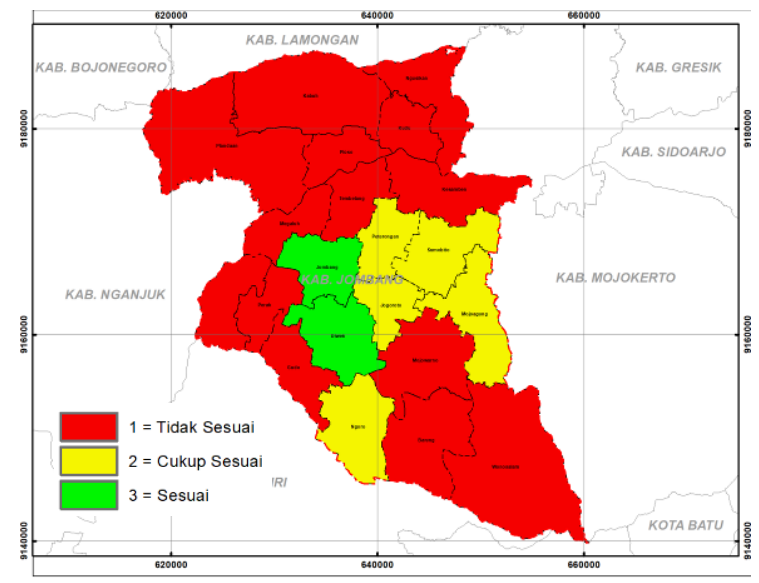

Gambar 10. Peta Jumlah Industri Sejenis

\section{G. Kriteria Kelembagaan}

Kriteria selanjutnya adalah kriteria kelembagaan. Pada kriteria kelembagaan terdapat dua sub kriteria yaitu sub kriteria jumla gabungan kelompok tani dan jumlah Koperasi Unit Desa (KUD).

Sub kriteria jumlah gabungan kelompok tani bertujuan untuk membina para petani agar mampu menjaga kuantitas produksi komoditas jagung. Dengan adanya Gapoktan pada tiap kecamatan akan mempermudah untuk mendapatkan bahan baku. untuk mengetahui tingkat kesesuaian lokasi agroindustri, maka dilakukan perhitungan dengan rumus interval.

$$
\begin{aligned}
\text { Interval } & =\frac{\text { Nilai Tertinggi }- \text { Nilai Terendah }}{\text { Jumlah Kelas }} \\
\text { Interval } & =\frac{38-1}{2} \\
& =18
\end{aligned}
$$

Oleh karena itu setiap kecamatan yang memiliki gapoktan lebih dari 19-38 diberi dinilai sesuai untuk lokasi agroindustri. Kecamatan yang memiliki 1-18 gapoktan dinilai cukup sesuai dengan lokasi agroindustri. Sementara kecamatan yang tidak memiliki gapoktan diilai tidak sesuai sebagai lokasi industri. Peta jumlah gabungan kelompok tani dapat dilihat pada gambar 11 .

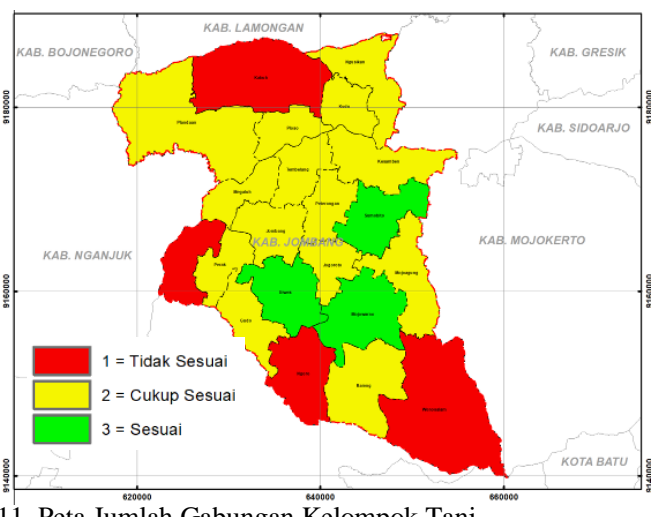

Gambar 11. Peta Jumlah Gabungan Kelompok Tani

Sub kriteria jumlah KUD bertujuan untuk adalah untuk mempermudah industri pengolahan untuk mendapatkan bahan baku. Proses untuk mendapatkan bahan baku akan lebih efisien apabila jalurnya lebih terkanalisasi. Untuk penyusunan sub kriteria KUD digunakan Keputusan Menteri Permukiman dan Prasarana Wilayah No. 534/KPTS/M/2001 tentang pedoman penentuan standar pelayanan minimal bidang penataan ruang. Dalam hal ini KUD digeneralisasi sebagai fasilitas perekonomian. Setiap 30.000 penduduk tersedia fasilitas perekonomian. Radius pelayanan fasilitas perekonomian tersebut diasumsikan dengan memperhatikan luas setiap kecamatan, sehingga didapatkan radius pelanan 35km (Destralita, 2015). Sehingga, kecamatan yang terlayani oleh KUD $<3$ km yang dapat memasok komoditas jagung dinilai sesuai sebagai lokasi agroindustri. Kecamatan yang termasuk dalam pelayanan KUD sejauh 3-5 km dikategorikan cukup sesuai. Sementara kecamatan yang berada pada radius pelayanan lebih dari 5km KUD dianggap tidak sesuai sebagai lokasi agroindustri. Peta keterlayanan KUD dapat dilihat pada gambar 12 . 


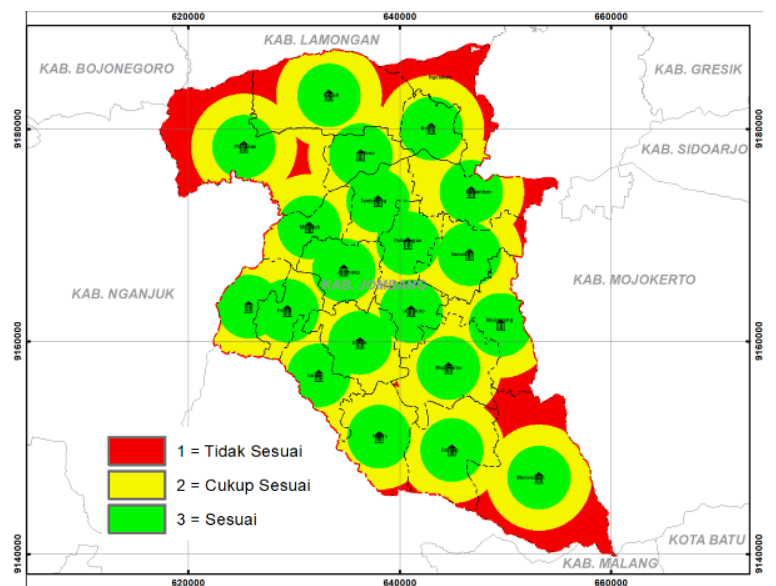

Gambar 12. Peta Keterlayanan KUD

\section{H. Kriteria Kesesuaian Lahan}

Kriteria kesesuaian lahan terdiri dari dua sub kriteria yaitu kesesuaian dengan arahan RTRW serta memenuhi jumlah minimum luas untuk industri.

Untuk sub kriteria kesesuaian lahan dengan arahan RTRW kegiatan industri harus sesuai dan mengacu kepada ketentuan yang ditetapkan dalam RTRW. Dokumen rencana tata ruang merupakan salah satu syarat bagi perizinan kegiatan industri. Hal tersebut dilakukan untuk mendapatkan lokasi yang cocok untuk lokasi agroindustri komoditas jagung yang ada di Kabupaten Jombang. Sehingga, lahan yang dipilih untuk lokasi industri adalah lahan non pertanian, non konservasi, dan non permukiman. Oleh karena itu lahan yang sesuai dengan kriteria lahan industri dinilai sesuai sebagai lokasi industri, area yang berada pada peruntukan selain industri dan lindung dinilai cukup sesuai, sementara lahan pertanian, konservasi, dan lahan permukiman dinilai tidak sesuai. Peta kesesuaian lahan dengan RTRW dapat dilihat pada gambar 13.

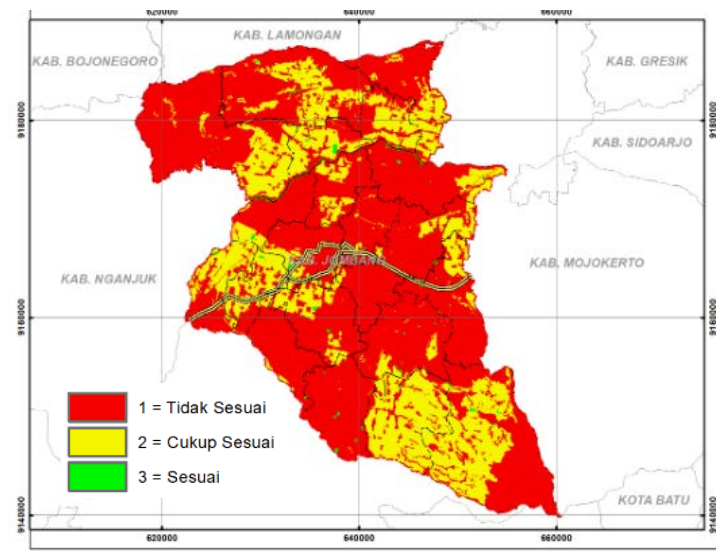

Gambar 13. Peta Kesesuaian Lahan dengan RTRW

Untuk sub kriteria luas minimum lahan yang dibutuhkan untuk industri pada industri skala sedang-besar harus dipertimbankan besar lahan yang dibutuhkan. Sehingga tidak terjadi upaya memaksakan diri untuk konversi lahan secara besar-besaran untuk pembangunan agroindustri. Menurut Peraturan Menteri Perindustrian nomor 40 tahun 2016 tentang pedoman teknis pembangunan kawasan industri, industri manufaktur membutuhkan lahan sebesar 1,34 ha. Sehingga lahan yang sesuai adalah yang memiliki luas minimum $>5$ ha dianggap sesuai sebagai lokasi agroindustri. Lahan yang memiliki luas antara 1,34-5 ha dinilai cukup sesuai Sementara lokasi yang kurang dari 1,34 ha dianggap tidak sesuai dengan lokasi agroindustri. Peta luas minimum lahan dapat dilihat pada gambar 14.

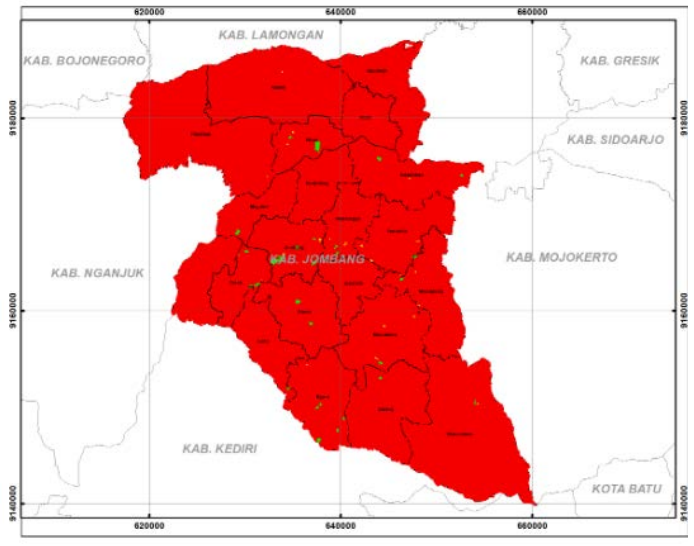

Gambar 14. Peta Luas Minimum Lahan yang dibutuhkan Industri

\section{KESIMPULAN}

Kriteria kondisi fisik dasar terdiri dari tiga sub kriteria. Sub kriteria kemiringan lahan area yang sesuai untuk kegiatan industri adalah dengan kemiringan 0-15\%, untuk sub kriteria jenis tanah, jenis tanah yang paling cocok untuk lokasi agroindustri adalah jenis tanah latosol dan mediteran dikarenakan memiliki tingkat keasaman yang tinggi sehingga menjadi kendala untuk pengembangan komoditas pertanian, untuk sub kriteria kerawanan bencana daerah bebas bencana dianggap sesuai untuk lokasi agroindustri.

Kriteria aksesibilitas terdiri dari sub kriteria ketersediaan jaringan jalan arteri. Dimana area yang terlayani adalah jaringan jalan yang memiliki klasifikasi jalan arteri primer dengan jangkauan koridor $5 \mathrm{~km}$ diartikan sesuai sebagai lokasi industri.

Kriteria tenaga kerja didefinisikan dengan jumlah usia produktif yang ada sehingga kecamatan dengan jumlah penduduk usia produktif sebanyak 14.868-43.706 dianggap kurang sesuai sebagai lokasi agroindustri.

Kriteria bahan baku untuk industri yaitu kecamatan yang memiliki produksi komoditas sejumlah 19.544-28.324 ton jagung dinilai sesuai untuk lokasi agroindustri.

Kriteria sarana dan prasarana terdiri dari tiga sub kriteria yaitu sub kriteria ketersediaan jaringan listrik, ketersediaan jaringan air, dan ketersediaan jaringan telekomunikasi. Untuk ketersediaan jaringan listrik kecamatan yang terlayani oleh jaringan listrik sejauh $<10 \mathrm{~km}$ dinilai sesuai sebagai lokasi agroindustri. untuk sub kriteria ketersediaan jaringan air bersih, kecamatan yang telah terlayani oleh jaringan air bersih dinilai sesuai sebagai lokasi agroindustri. Untuk sub kriteria ketersediaan jaringan telekomunikasi kecamatan dengan jumlah industri sebanyak 4-6 unit dianggap paling sesuai sebagai lokasi agroindustri.

Untuk kriteria aglomerasi, kecamatan dengan jumlah industri sebanyak 4-6 unit dianggap paling sesuai sebagai lokasi agroindustri

Kriteria kelembagaan terdiri dari dua sub variabel yaitu sub kriteria jumlah gabungan kelompok tani dimana setiap kecamatan yang memiliki gapoktan lebih dari 19-38 diberi dinilai sesuai untuk lokasi agroindustri. dan untuk sub kriteria keterlayanan KUD adalah kecamatan yang terlayani oleh KUD $<3$ km yang dapat memasok komoditas jagung dinilai sesuai sebagai lokasi agroindustri.

Kriteria kesesuaian lahan terdiri dari dua sub kriteria yaitu sub kriteria kesesuaian lahan dengan arahan RTRW dimana lahan yang sesuai dengan kriteria lahan industri dinilai sesuai sebagai lokasi industri. Untuk sub kriteria luas lahan minimum yang dibutuhkan oleh industri yaitu lahan yang 
sesuai adalah yang memiliki luas minimum $>5$ ha dianggap sesuai sebagai lokasi agroindustri.

\section{DAFTAR PUSTAKA}

[1] S. Suprapto, "Karakteristik, penerapan, dan pengembangan agroindustri hasil pertanian di Indonesia.” 2002.

[2] BPS Kabupaten Jombang, Kabupaten Jombang dalam angka 2017. Jombang: BPS Kabupaten Jombang, 2017.

[3] BPS Kabupaten Jombang, PDRB Kabupaten Jombang tahun 2012-2016. Jombang: BPS Kabupaten Jombang, 2017.

[4] H. Hidayah, "Pengembangan agroindustri berbasis komoditas pertanian unggulan di Kabupaten Jombang,” Institut Teknologi Sepuluh Nopember, 2016.

[5] BPS Provinsi Jawa Timur, Direktori perusahaan industri besar dan sedang Provinsi Jawa Timur. Surabaya: BPS Provinsi Jawa Timur, 2017.

[6] A. . Matori and B. . Aulia, "Suitability analysis of petrol filling station site using GIS,” Malaysian Constr. Res. J., vol. 7, no. 2, p. 2010.
[7] B. U. Aulia, "Siting suitability analysis of petrol filling station using GIS and analytical hierachy process: A case study of Surabaya metropolitan,” Universiti Teknologi PETRONAS, UTP, 2011.

[8] B. U. Aulia, W. Utama, and P. G. Ariastita, "Location analysis for petrol filling station based on stakeholders' preference and seismic microzonation,” Procedia - Soc. Behav. Sci., vol. 227, pp. 115123, Jul. 2016.

[9] N. C. Drestalita and D. Rahmawati, "Kriteria zona industri pendukung pengembangan kawasan agropolitan di Kabupaten Tuban,” J. Tek. ITS, vol. 4, no. 2, pp. C133-C138, Feb. 2016.

[10] M. I. Affandi, "Peran agroindustri dalam perekonomian wilayah Provinsi Lampung: analisis keterkaitan antarsektor dan aglomerasi industri,” IPB (Bogor Agricultural University), 2009.

[11] F. Fitrianingrum, "Penentuan Lokasi Agroindustri Berbasis Komoditas Jagung di Kabupaten Jombang,” Institut Teknologi Sepuluh Nopember, 2018. 